\title{
総合健診における乳房全例超音波検査について
}

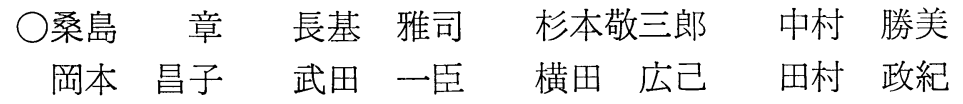

乳腺腫瘤の超音波による鑑別參断には乳腺専用装置が 最適であるが，取扱いに熟練と時間を要し，多数例を対 象とするスクリーニングには利用しにくい。取扱いの簡 便なリアルタイム電子走査装置は, 超音波像の画質は専 用装置に及ばないとして屯, 短時間に乳腺全体を検査で きる上に，リアルタイム走査のため腫瘤を見逃す危険が 少ない利点がある。

当センターの健診では, 従来, 乳腺超音波検査につい ては診察医の指示にあった例のみに限定していたが, 昭 和 61 年 2 月より, 女性の健診者全員汇乳腺超音波検査 を始めた。装置は腹部用の電子走査装置日立 EUB 40 亿 $5 \mathrm{MHz}$ のリニア型プローブを装着し, 本学会第 13 回大 会に発表した手作りの水袋ホルダーを装着した。

対象は昭和 61 年 2 月から 7 月までの 6 力月間の女性 健診者 3,197 名である。乙のうち超音波で所見のみられ たのは 337 例，有所見率 $10.5 \%$ であった。超音波彰断 名は乳腺症の 228 例があっと屯多く, ついで穓胞の 103 例, 充実性腫瘍 27 例, 豊胸術後 4 例, 石灰化 1 例の順 であった。充実性腫湯は内部エコーの均一性, 境界の整 不整，音響透過性などによって，がんの疑いが大きいも の 4 例, 線維腺腫と彮断したもの 15 例, 線維腺腫之考 えられるが腫瘤が小さいため線維腺腫疑いとしたあの 8 例の 3 群に分けた。がんの疑いが大きいものは手術可能 な他の医療施設へ紹介し，がんの可能性の小さいものは 当センターにて再検査ならびに経過観察を行った。最終 的にがんと病理学的に診断されたものは 2 例であった。 がんの疑いとした 4 例中組織学的にがんは 1 例, 良性腫 瘍 1 例, 他の医療施設で良性病変とされたもの 2 例であ った。超音波で線維腺腫とした 15 例中 1 例はがんであ った。

最終的にがんと診断された 2 症例を提示する。第 1 例
は 49 歳女後, 当センターでの 7 回目のドックを昭和 61 年 7 月に受けた。触診では乳腺に腫瘤を触知せず，超音 波にて右乳腺内上部すなわち $\mathrm{A}$ 領域に直径 $9 \times 9 \mathrm{~mm}$ の 充実性腫瘤をみとめ, 内部均一ではあるが境界がわずか に不整であり，かつ音響透過性の低下が観察されたた め, 8 週後に再検したところ腫瘤の増大傾向をみとめ, 某大学附属病院紹介し 12 月に手術となった。病理所見 は $10 \times 8 \mathrm{~mm}$ の硬癌であり, Stage Iであったため胸筋 保存手術が行われた。リンパ節転移は認められなかっ た。

第 2 例は 31 歳女性, 左乳腺外側 $\mathrm{C}$ および $\mathrm{D}$ 領 域に直 径 $15 \mathrm{~mm}$ の弾性硬で可動性のある腫瘤を触知する。超 音波では内部やや不均一ながら境界明瞭で整であり，音 響透過性の低下をみとめなかったため, 線維腺腫と診断 した。9 週後の再検では大きさの変化はみとめられなか ったが，さらに 8 週後に再検したところ直径 $20 \mathrm{~mm}$ と あきらかな増大傾向を示したので，某医療施設紹介，手 術を受け組織学的にはこれも硬癌であった。

リアルタイム電子走査装置による腹部のスクリーニン グに引き続いて，水袋ホルダーを装着した体表用プロー ブに接続を切り換えて乳腺超音波検査を行うことによっ て，検查時間のわずかな増加で女性全例乳腺超音波検査 が可能となった。今回の集計の結果，2 例の乳癌を超音 波で診断しえたが，うち 1 例が触診では触知しえず，超 音波ではじめて部断しえた直径約 $1 \mathrm{~cm}$ の小さい乳癌で あったととは乳腺全例超音波検查の意義があったものと 考えている。さらに, 今後, 当センタ一の受㟝者に乳腺 腫瘤が発見された場合, 前回の乳腺超音波検査フィルム が残っているととは腫瘤の鑑別診断に役立つあのと考え ている。

\section{Ultrasonic Screening of Mammary Glands in AMHTS}

PL 東京健康管理センター 